\title{
Proteinuria in Dent disease: a review of the literature
}

\author{
Youri van Berkel $^{1}$ - Michael Ludwig ${ }^{2}$ • Joanna A. E. van Wijk ${ }^{1}$ Arend Bökenkamp ${ }^{1}$
}

Received: 26 April 2016/Revised: 23 August 2016 / Accepted: 25 August 2016 / Published online: 18 October 2016

(C) The Author(s) 2016. This article is published with open access at Springerlink.com

\begin{abstract}
Background Dent disease is a rare $\mathrm{X}$-linked recessive proximal tubulopathy caused by mutations in CLCN5 (Dent-1) or OCRL (Dent-2). As a rule, total protein excretion (TPE) is low in tubular proteinuria compared with glomerular disease. Several authors have reported nephrotic-range proteinuria (NP) and glomerulosclerosis in Dent disease. Therefore, we aimed to analyze protein excretion in patients with documented CLCN5 or OCRL mutations in a systematic literature review.

Design PubMed and Embase were searched for cases with documented CLCN5 or OCRL mutations and (semi-)quantitative data on protein excretion. The most reliable data (i.e., TPE $>$ protein-creatinine ratio $>$ Albustix) was used for NP classification.

Results Data were available on 148 patients from 47 reports: 126 had a CLCN5 and 22 an OCRLmutation. TPE was not significantly different between both forms $(p=0.11)$. Fiftyfive of 126 (43.7 \%) Dent-1 vs 13/22 (59.1\%) Dent-2 patients met the definition of NP $(p=0.25)$. Serum albumin was normal in all reported cases (24/148). Glomerulosclerosis was noted in 20/32 kidney biopsies and was strongly related to tubulointerstitial fibrosis, but not to kidney function or proteinuria.

Conclusion More than half of the patients with both forms of Dent disease have NP, and the presence of low molecular weight proteinuria in a patient with NP in the absence of
\end{abstract}

Arend Bökenkamp

a.bokenkamp@vumc.nl

1 Department of Pediatric Nephrology, VU University Medical Center, De Boelelaan 1117, 1081 HV Amsterdam, The Netherlands

2 Department of Clinical Chemistry and Clinical Pharmacology, University of Bonn, Bonn, Germany edema and hypoalbuminemia should prompt genetic testing. Even with normal renal function, glomerulosclerosis and tubulointerstitial fibrosis are present in Dent disease. The role of proteinuria in the course of the disease needs to be examined further in longitudinal studies.

Keywords Dent disease - CLCN5 - OCRL · Proteinuria · Nephrotic syndrome $\cdot$ Low-molecular weight proteinuria . Systematic review

\section{Introduction}

Dent disease, a rare $\mathrm{X}$-linked recessive tubulopathy, was first described in 1964 in two unrelated cases presenting with renal tubular rickets, hypercalciuria, and tubular proteinuria [1]. Dent disease is characterized by low molecular weight (LMW) proteinuria, hypercalciuria, nephrolcalcinosis or nephrolithiasis, variable manifestations of proximal tubular dysfunction, and progressive renal failure, ultimately resulting in end-stage renal failure in adulthood [2-5].

In about $60 \%$ of patients with X-linked nephrolithiasis, a mutation in the CLCN5 gene is detected, whereas in $15 \%$, the disease is due to a mutation in the $O C R L$ gene. For the remaining $25 \%$, no specific gene defect has been described as yet [6]. Patients with a mutation in $C L C N 5$ are classified as having Dent disease type 1 (Dent-1; MIM \#300009), while patients with a mutation in $O C R L$ are classified as Dent disease type 2 (Dent-2; MIM \#300555). The renal phenotype of Dent2 is comparable with that of Dent- 1 except for a lower prevalence of nephrocalcinosis $[7,8]$. The exact prevalence of Dent disease is unknown; to date, $>250$ families have been described [9].

Under normal conditions, LMW proteins, which pass the glomerular membrane extensively [10], are almost completely 
reabsorbed in the proximal tubule by megalin-cubilin receptor-mediated endocytosis and therefore do not appear in the final urine. As $C L C N 5$ and $O C R L$ mutations impair the function of the megalin-cubilin system, the loss of LMW proteins is an obligate finding in Dent disease [11]. As a rule, total protein excretion is low in tubular proteinuria compared with glomerular disease, mostly around $1 \mathrm{~g} / \mathrm{l}$, and rarely exceeds $2 \mathrm{~g} / 1$ [12]. Frishberg et al. [2], Copelovitch et al. [13], and Fervenza [14] reported nephrotic-range proteinuria (NP) in patients with documented CLCN5 mutations and histological findings of focal segmental glomerulosclerosis (FSGS) or focal global glomerulosclerosis. They suggested that Dent-1 disease is an underdiagnosed etiology of FSGS and might reflect a yet unrecognized glomerular dysfunction in Dent-1, while data on proteinuria in Dent-2 are sparse [15]. Therefore, the objective of this study was to analyze protein excretion and histology in patients with documented CLCN5 or OCRL mutation disease by means of a systematic literature review (Fig. 1).

\section{Methods}

Our search was performed using the bibliographic search engines PubMed and Embase using the following search strategy:

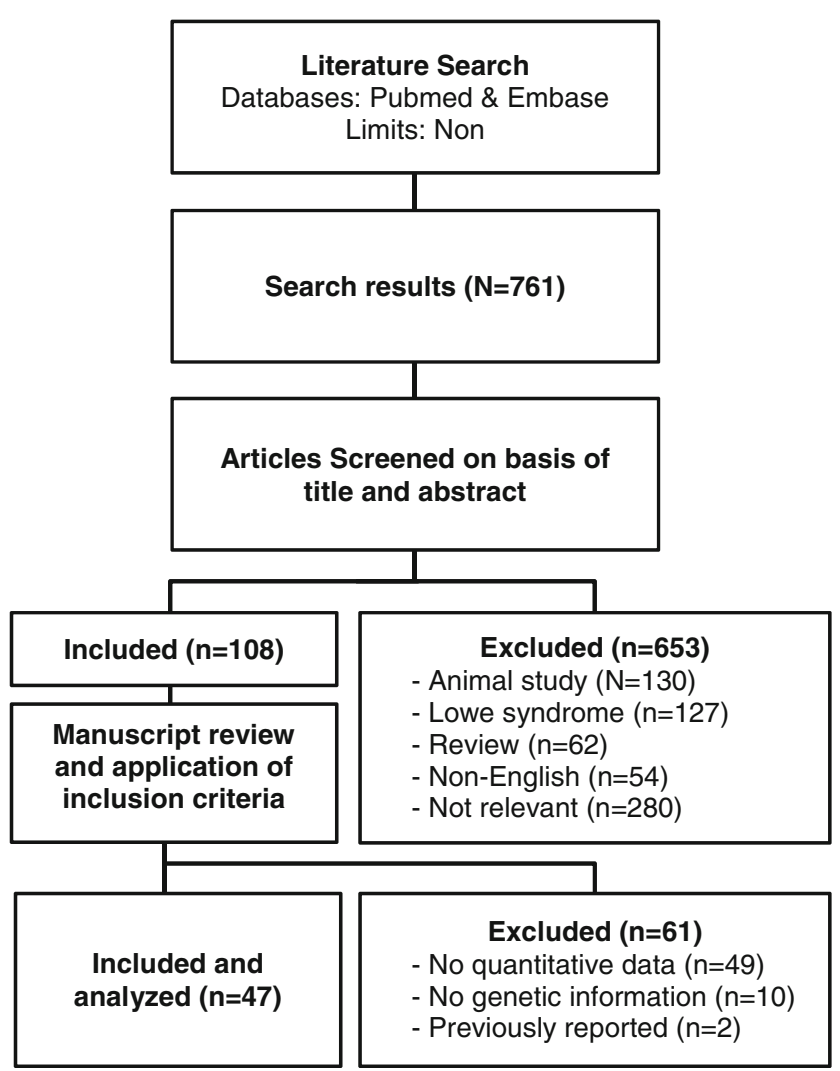

Fig. 1 Study flow
For Dent-1: [Dent's disease OR Dents disease OR Dent disease OR Dent Disease (Mesh)] AND [CLCN5 OR CLCN-5 OR CLCN 5 OR CLCN OR CLC-5 chloride channel (Supplementary Concept) OR Dent disease 1 (Supplementary Concept)]

For Dent-2: Dent's disease OR Dents disease OR Dent disease OR Dent Disease (Mesh)] AND [OCRL1 OR OCRL-1 OR OCRL 1 OR OCRL OR Dent disease 2 (Supplementary Concept)].

The combined search on Embase and PubMed yielded a total of 761 unique records, all of which were screened manually by title and abstract by two independent researchers (YvB and $\mathrm{AB}$ ). Inclusion criteria were papers describing (i) Dent disease patients with documented CLCN5 or OCRL mutations, and (ii) presenting quantitative or semiquantitative data on proteinuria. Main exclusion criteria were cases with extrarenal findings, suggesting Lowe syndrome in $O C R L$-positive patients, and papers reporting female carriers only. Only papers published in English were considered for review. The reference lists of the respective papers were checked for publications missed by the search strategy.

Data on total protein excretion were extracted if presented as (i) semiquantitative Albustix in a spot urine sample (Sticks), (ii) protein-creatinine ratio in a spot urine sample $(\mathrm{P} / \mathrm{C})$, or (iii) as protein excretion in a timed urine collection. Timed protein excretion (TPE) was related to total body surface area (BSA) and presented as milligrams per meter ${ }^{2}$ per hour. BSA was calculated from weight and height using the Mosteller formula [16]. In 54 patients with documented timed proteinuria, no height/weight data were available, however. In these cases, BSA was estimated as follows: in adults, a standard BSA of $1.73 \mathrm{~m}^{2}$ was used, while in children, height and weight were extrapolated using Dutch reference data of gender- and age-specific medians for height and weight [17]. To validate this approach, we compared TPE based on extrapolated BSA, with TPE calculated from documented height and weight in 28 patients. Median TPE based on extrapolated BSA was $52.1 \mathrm{mg} / \mathrm{m}^{2} / \mathrm{h}$ [interquartile range (IQR) $40.3-$ 71.2] compared with $51.6 \mathrm{mg} / \mathrm{m}^{2} / \mathrm{h}$ with documented height and weight (IQR 35.8-71.6, $p=0.699$, Wilcoxon test), indicating that our approach yields valid results. If TPE was expressed as milligrams per kilogram per day, it was transformed into milligrams per meter ${ }^{2}$ per hour by analogy.

The following definitions were used: LMW proteinuria was defined as increased excretion of either $\beta_{2}$ microglobulin $(\beta 2 \mathrm{M})(>0.3 \mathrm{mg} / \mathrm{l}$ or $>0.3 \mathrm{mg} / \mathrm{g}$ creatinine $)$, retinol-binding protein (RBP) $\left(>0.1 \mathrm{mg} / \mathrm{l}\right.$ or $>0.1 \mathrm{mg} / \mathrm{g}$ creatinine), or $\alpha_{1}$ microglobulin $(\alpha 1 \mathrm{M})(>12 \mathrm{mg} / 1$ or $>11.7 \mathrm{mg} / \mathrm{g}$ creatinine) $[18$, 19]. NP was defined as TPE $>40 \mathrm{mg} / \mathrm{m}^{2} / \mathrm{h}$ [20] or $\mathrm{P} / \mathrm{C}>$ $1800 \mathrm{mg} / \mathrm{g}$ creatinine (corresponding to $>200 \mathrm{mg} / \mathrm{mmol}$ creatinine) [21] or Sticks 3+ [21]. If more than one parameter was available, the most reliable (i.e. TPE $>\mathrm{P} / \mathrm{C}>$ sticks) was used 
for NP classification. Unless glomerular filtration rate (GFR) was stated in the paper, it was estimated using the Schwartz equation in children [22] or the four variable Modification of Diet in Renal Disease (MDRD) equation in adults [23]. As functional data are lacking for most mutations, mutations leading to messenger RNA (mRNA) decay or premature termination of the resultant OCRL-1 or ClC-5 protein (i.e., stop, frameshift, gross deletion) were classified as severe, while frame and missense mutations were classified as moderate [24].

Serial data were available on only 13 patients. In these cases, data at presentation were used. Statistical analysis was performed using SPSS version 22 [25]. Data are presented as median [interquartile range (IQR)] and were analyzed using nonparametric tests (chi-square and Mann-Whitney $U$ ). Differences were considered significant at $p<0.05$, and $p$ $<0.1$ was considered as a statistical trend.

\section{Results}

\section{Study characteristics}

As of 1 March 2016, the PubMed and Embase search yielded a total of 761 publications after removing 499 duplicates. Six hundred and fifty-three were excluded based on title and abstract (130 involved animal studies, 127 reported on Lowe syndrome, 62 were reviews, 54 were not in English, and 280 were irrelevant to our study). The remaining 108 articles were reviewed in full text: 61 were excluded (49 presented nonquantitative data, diagnosis of Dent disease had not been confirmed genetically in ten, and two papers contained cases already reported in another publication). In total, 47 articles describing 148 patients were included [2, 5, 13-15, 26-67]. The median number of patients per publication was two (IQR 1-5). Sixty-one patients were reported in papers from Japan, China, Korea, or India; 24 from North America; three from South America; 55 from the Mediterranean; and five from Northern Europe. One hundred and-twenty-six patients had a CLCN5 and 22 an OCRL mutation. Median age was 8.5 years (IQR 4-13) in Dent-1 and 9 years (IQR 4-10.5) in Dent-2. Data on GFR were available in 110 patients with Dent- 1 and 19 with Dent-2. Here, too, no significant difference was found $\left[110.5 \mathrm{ml} / \mathrm{min} / 1.73 \mathrm{~m}^{2}\right.$ (IQR 79-143) vs. $108 \mathrm{ml} / \mathrm{min} / 1.73 \mathrm{~m}^{2}$ (IQR 94-130); $\left.p=0.971\right]$.

\section{Proteinuria}

Data on proteinuria are presented in Table 1. In the majority of patients, TPE was reported. There was no difference in proteinuria between Dent-1 and Dent- 2 patients based on TPE, while Dent-2 patients scored higher when proteinuria was tested by urinary dipstick. In both groups, almost half of the patients had NP. Quantitative LMW proteinuria was reported in 134 patients. $\beta 2 \mathrm{M}$ was by far the most frequently measured LMW protein and was reported in $85.1 \%$ of patients; the vast majority of papers reported LMW protein concentrations rather than LMW protein/creatinine ratios or TPE. This was also the case for urinary albumin excretion, which was reported in only 11 patients [median $200 \mathrm{mg} / \mathrm{l}$ (IQR 80-310)]. This precluded further analysis of urinary protein composition. There was no significant relationship between TPE and GFR $\left(r^{2}=\right.$ $0.032, p=0.15$ ). Accordingly, GFR was comparable between patients with and without NP $\left[104.1 \mathrm{ml} / \mathrm{min} / 1.73 \mathrm{~m}^{2}\right.$ (IQR 79-121.6) vs. $118.3 \mathrm{ml} / \mathrm{min} / 1.73 \mathrm{~m}^{2}$ (IQR 83.6-173.9); $p=$ $0.327)$ ] There was no single report mentioning edema formation in Dent patients. Serum albumin was reported in 24 cases: median concentration was 46.5 (39-54) g/l.

Information on renin-angiotensin-aldosterone system (RAAS) inhibition was available for eight patients only. Angiotensin-converting enzyme (ACE) inhibitors or angiotensin II receptor blockers (ARB) were prescribed for eight Dent-1 patients (Table 2): all but one had NP; a reduction of proteinuria of $50 \%$ was reported for two; proteinuria remained unchanged in four. In one patient, RAAS inhibition was discontinued because of rapidly rising serum creatinine. In two others, GFR halved within 4 and 7 years, respectively.

\section{Mutation}

In 44 of 148 patients (29.7\%), mutation severity was classified as moderate. In this group, the prevalence of NP was comparable with patients harboring a severe mutation (52.3\% vs $43.3 \%, p=0.368)$, as was proteinuria [TPE $60.0 \mathrm{mg} / \mathrm{m}^{2} / \mathrm{h}$ (IQR 39.9-77.6) vs. $46.1 \mathrm{mg} / \mathrm{m}^{2} / \mathrm{h}$ (IQR $36.5-64.2, p=0.205)$ and GFR $\left[113.9 \mathrm{ml} / \mathrm{min} / 1.73 \mathrm{~m}^{2}(\mathrm{IQR}\right.$ 74.4-162.4) vs $108.2 \mathrm{ml} / \mathrm{min} / 1.73 \mathrm{~m}^{2}$ (IQR 81-138), $p=$ $0.584)$.

\section{Kidney biopsy}

Kidney biopsy data were reported in 34 patients: 31 Dent-1 and three Dent-2. Proteinuria [TPE $52.1 \mathrm{mg} / \mathrm{m}^{2} / \mathrm{h}$ (IQR 3969) vs. $48.8 \mathrm{mg} / \mathrm{m}^{2} / \mathrm{h}$ (IQR 37-78), $\left.p=0.80\right)$ and GFR [118 ml/min/1.73 $\mathrm{m}^{2}$ (IQR 83-166) vs. $109 \mathrm{ml} / \mathrm{min} /$ $1.73 \mathrm{~m}^{2}$ (IQR 79-140), $\left.p=0.51\right]$ were comparable between biopsied and nonbiopsied patients. Median age at biopsy was 9 years, which is identical with the median age of the total cohort. Table 3 summarizes biopsy results. In ten patients, glomeruli were reported to be normal; in two, immature glomeruli were noted; and in two, no information was provided. Glomerular sclerosis was noted in 20 of the 32 biopsies describing glomerular morphology (63\%), namely, focal global glomerulosclerosis $(N=18)$ rather than FSGS $(N=5)$. In patients in whom 
Table 1 Proteinuria in Dent-1 and Dent-2 patients

\begin{tabular}{|c|c|c|c|c|}
\hline & Total & Dent-1 & Dent-2 & $P$ value \\
\hline Dipstick $(n)$ & $N=63$ & $N=52$ & $N=11$ & \multirow[t]{5}{*}{0.02} \\
\hline $1+$ & $18(27.3 \%)$ & $17(30.9 \%)$ & $1(9.1 \%)$ & \\
\hline $2+$ & $40(60.6 \%)$ & $34(61.8 \%)$ & $6(54.5 \%)$ & \\
\hline $3+$ & $7(10.6 \%)$ & $3(5.5 \%)$ & $4(36.4 \%)$ & \\
\hline $4+$ & $1(1.5 \%)$ & $1(1.8 \%)$ & $0(0 \%)$ & \\
\hline $\mathrm{P} / \mathrm{C}(\mathrm{mg} / \mathrm{g})$ & $\begin{array}{l}N=23 \\
2800(2100-4104)\end{array}$ & $\begin{array}{l}N=20 \\
2850(1835-4900)\end{array}$ & $\begin{array}{l}N=3 \\
2718 \text { (NA) }\end{array}$ & $N A$ \\
\hline $\mathrm{TPE}\left(\mathrm{mg} / \mathrm{m}^{2} / \mathrm{h}\right)$ & $\begin{array}{l}N=83 \\
49.0(38.1-69.1)\end{array}$ & $\begin{array}{l}N=71 \\
47.0(37.3-67.4)\end{array}$ & $\begin{array}{l}N=12 \\
57.5(41.8-81.1)\end{array}$ & 0.11 \\
\hline $\mathrm{NP}(N / N)$ & $68 / 148(45.9 \%)$ & $55 / 126(43.7 \%)$ & $13 / 22(59.1 \%)$ & 0.25 \\
\hline
\end{tabular}

Data presented as number $(\%)$ of cases or as median and interquartile range (IQR)

$P / C$ protein-creatinine ratio, TPE timed protein excretion, $N P$ nephrotic-range proteinuria

glomerulosclerosis was quantified, a median of $13 \%$ (IQR 6-26) of glomeruli was affected. Only four papers reported electron microscopy data on glomerular foot processes: in a single patient [44], foot-process effacement was noted; in the other three, electron microscopy was normal $[27,36$, 42]. Tubulointerstitial fibrosis was present in 14 of 29 patients $(48 \%)$ and nephrocalcinosis in ten of $14(71 \%)$ in whom these features were reported. Contingency table analysis between glomerular sclerosis and tubulointerstitial fibrosis showed a highly significant association $\left(\chi^{2}=19.1\right.$, $p=0.001$ ). There was no statistical difference in median TPE with respect to glomerulosclerosis [with $49.1 \mathrm{mg}$ / $\mathrm{m}^{2} / \mathrm{h}$ (IQR $37-78$ ) vs. without $65.8 \mathrm{mg} / \mathrm{m}^{2} / \mathrm{h}$ (IQR $52-$ $69), p=0.1$ ] or tubulointerstitial fibrosis [with $49.1 \mathrm{mg} /$ $\mathrm{m}^{2} / \mathrm{h}$ (IQR 33-84) vs. without $61.8 \mathrm{mg} / \mathrm{m}^{2} / \mathrm{h}$ (IQR $47-$ $68), p=0.238]$. Of note, both histological findings appeared to be associated with less rather than more proteinuria.

\section{Discussion}

We demonstrated that NP is a common finding in Dent disease both in patients with CLCN5 and OCRL mutations. Still, patients do not present with the other two characteristics of nephrotic syndrome (NS), i.e., edema formation or hypoalbuminemia. Therefore, the finding of isolated NP should prompt analysis for LMW proteinuria. Although LMW proteinuria can be seen as a result of overflow proteinuria in patients with massive proteinuria, this phenomenon is not observed in the proteinuria range of Dent patients [68]. Two mechanisms may be involved in the pathogenesis of NP in Dent disease: defective uptake of physiologically filtered albumin and other proteins, or an additional glomerulopathy as suggested by the presence of glomerulosclerosis on renal biopsy [2, 13, 14].

Although it was held that $C L C N 5$ is only expressed in proximal tubuli and collecting ducts, Ceol et al. recently showed CLCN5 expression in human podocytes [69]. As CLCN5

Table 2 Renin-angiotensin-aldosterone system (RAAS) inhibitor use

\begin{tabular}{|c|c|c|c|c|c|c|c|c|}
\hline Author & $\begin{array}{l}\text { Patient } \\
\text { ID }\end{array}$ & Mutation & $\begin{array}{l}\text { Age } \\
\text { (years) }\end{array}$ & $\begin{array}{l}\text { ACE } \\
\text { inhibitor }\end{array}$ & $\mathrm{ARB}$ & $\mathrm{T}=0$ & $\mathrm{~T}=1$ & $\begin{array}{l}\text { Treatment } \\
\text { duration }\end{array}$ \\
\hline Copelovitch et al. [13] & Patient 1 & CLCN5 & 12 & Yes & No & Proteinuria: $50 \mathrm{mg} / \mathrm{kg} /$ day & Proteinuria: $25 \mathrm{mg} / \mathrm{kg}$ day & 2 months \\
\hline \multirow[t]{2}{*}{ Frishberg et al. [2] } & Patient 1 & CLCN5 & 9 & Yes & Yes & NA & No effect on proteinuria & $N A$ \\
\hline & Patient 3 & CLCN5 & 14 & Yes & Yes & $N A$ & No effect on proteinuria & $N A$ \\
\hline Lim et al. [44] & Case 1 & CLCN5 & 3 & Yes & No & $N A$ & $50 \% \mathrm{P} / \mathrm{C}$ reduction & 6 months \\
\hline Marsenic et al. [47] & Patient 1 & CLCN5 & 13 & Yes & No & $N A$ & Strong rise in serum creatinine & $N A$ \\
\hline Okamoto et al. [52] & Case 1 & CLCN5 & 3 & Yes & No & GFR $73 \mathrm{ml} / \mathrm{min} / 1.73 \mathrm{~m}^{2}$ & GFR $30 \mathrm{ml} / \mathrm{min} / 1.73 \mathrm{~m}^{2}$ & 7 years \\
\hline \multirow[t]{2}{*}{ Vaisbich et al. [63] } & Case 1 & CLCN5 & 11 & Yes & No & $\begin{array}{l}\text { Proteinuria: } 51 \mathrm{mg} / \mathrm{kg} \text { day } \\
\text { GFR } 66 \mathrm{ml} / \mathrm{min} / 1.73 \mathrm{~m}^{2}\end{array}$ & $\begin{array}{l}\text { Proteinuria: } 65 \mathrm{mg} / \mathrm{kg} \text { day } \\
\text { GFR } 65 \mathrm{ml} / \mathrm{min} / 1.73 \mathrm{~m}^{2}\end{array}$ & 3 years 5 months \\
\hline & Case 2 & CLCN5 & 4 & Yes & No & $\begin{array}{l}\text { Proteinuria: } 65 \mathrm{mg} / \mathrm{kg} \text { day } \\
\text { GFR } 172 \mathrm{ml} / \mathrm{min} / 1.73 \mathrm{~m}^{2}\end{array}$ & $\begin{array}{l}\text { Proteinuria: } 60 \mathrm{mg} / \mathrm{kg} \text { day } \\
\text { GFR } 95 \mathrm{ml} / \mathrm{min} / 1.73 \mathrm{~m}^{2}\end{array}$ & 4 years \\
\hline
\end{tabular}

$A R B$ angiotensin II receptor-blockers, $A C E$ angiotensin-converting enzyme, $G F R$ glomerular filtration rate, $T=0$ before therapy, $T=1$ during therapy 


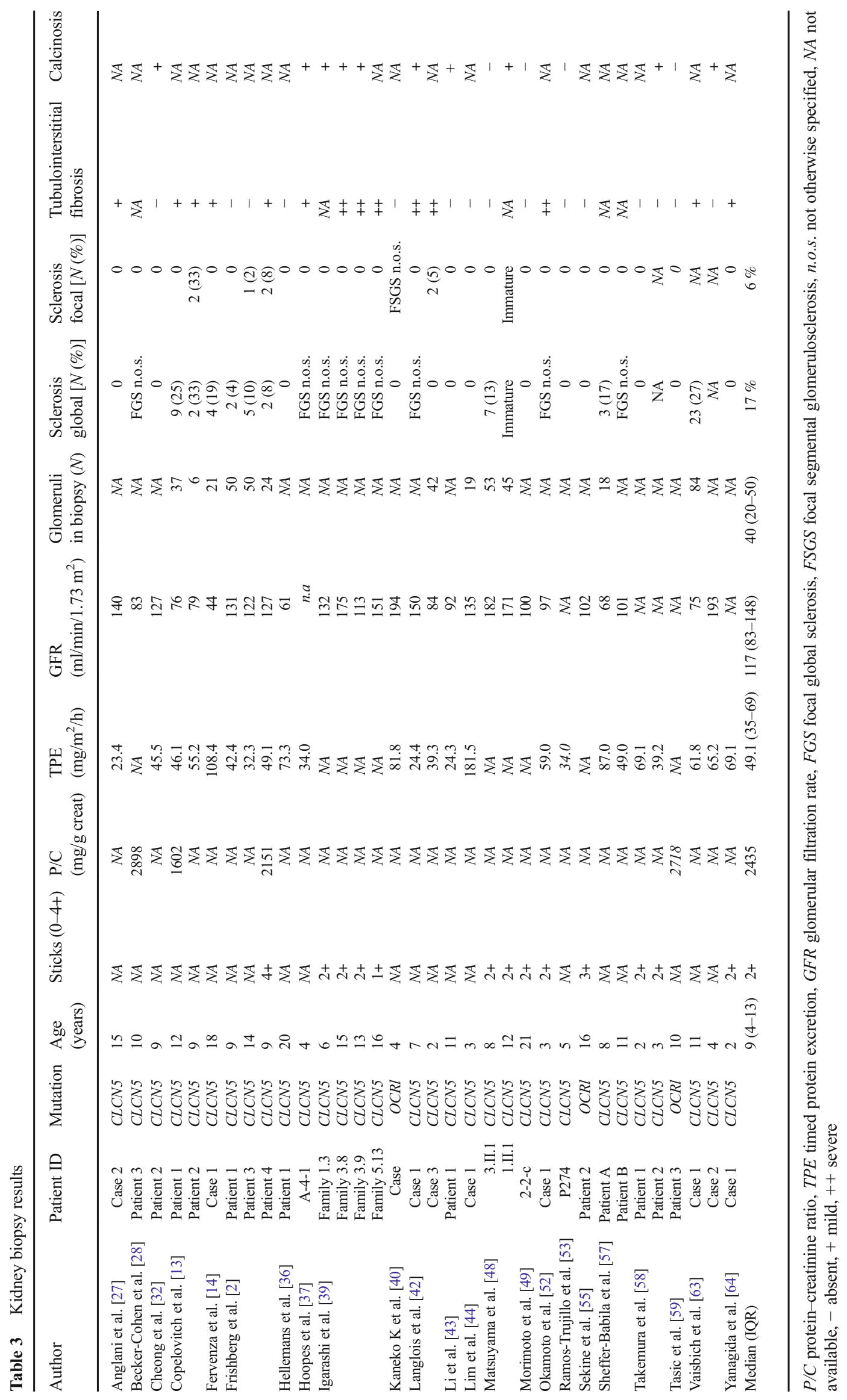


appeared to be overexpressed in proteinuric states, the authors speculate that podocytes have an endocytic machinery similar to the proximal tubular cell. This has been linked to the finding of glomerulosclerosis in Dent-1 patients [14]. Studies in rabbits showed that $O C R L$, too, is expressed in glomeruli [70]. This prompted us to compare the proteinuric phenotype in both forms of Dent disease, which share a common metabolic pathway in the proximal tubule. In line with findings on renaltubular dysfunction in both patient groups [11], we found that proteinuria was virtually identical, suggesting defective protein uptake as the underlying mechanism.

Can defective protein uptake by the megalin-cubilin complex alone account for the amount of proteinuria observed in these patients? While LMW proteins are almost freely filtered across the glomerular membrane, there is much controversy about glomerular albumin filtration, with sieving coefficients ranging from 0.0006 to 0.074 in different rat models [71]. This has recently been reviewed by Dickson et al., who suggest that glomerular albumin filtration is higher than previously thought and that part of the filtered albumin is reabsorbed intact via transcytosis involving the neonatal Fc receptor [72]. Norden et al. studied patients with Dent disease to calculate the glomerular sieving coefficients of albumin, immunoglobulin (Ig) $\mathrm{G}$ and other plasma proteins in vivo, assuming that in these patients, urinary protein excretion directly reflects glomerular protein filtration [10]. They report a sieving coefficient for albumin of 0.00008 and a mean urine albumin/creatinine ratio of $38 \mathrm{mg} / \mathrm{mmol}$ (i.e. $342 \mathrm{mg} / \mathrm{g}$ creatinine).

In another study on tubular proteinuria in Dent disease, Norden et al. reported a linear relationship between the albumin/creatinine ratio and the creatinine-corrected concentrations of retinol-binding protein, $\beta 2 \mathrm{M}$, and alpha- 1 microglobulin, all of which were around $20-30 \mathrm{mg} / \mathrm{mmol}$ creatinine (i.e., $180-270 \mathrm{mg} / \mathrm{g}$ ) [18]. The sum of the mean albumin, retinolbinding protein, $\beta 2 \mathrm{M}$, and alpha-1 microglobulin concentrations standardized for urine creatinine was $100 \mathrm{mg} / \mathrm{mmol}$ (i.e., $900 \mathrm{mg} / \mathrm{g}$ ), which is about one third of the proteinuria observed in our study. This probably reflects the multitude of other LMW proteins and polypeptides undergoing tubular reabsorption, which were not measured in their study. Of note, intermittent nephrotic-range proteinuria has also been observed in a pair of siblings with a mutation in $C U B N$ encoding for cubilin, whereas most of these patients only have LMW proteinuria [73].

Kidney biopsy data were only available for $20 \%$ of patients and might be flawed by a reporting bias. Still, patient age, renal function, and amount of proteinuria were identical to those of nonbiopsied patients. When reported, the number of glomeruli was sufficient to exclude a serious sampling error. The finding of glomerulosclerosis in almost two thirds of the biopsies (with a median of $17 \%$ glomeruli being sclerosed) underscores the concerns about glomerular pathology in Dent disease. However, glomerulosclerosis was mostly focal global rather than focal segmental $[2,13,14]$. The absence of foot-process effacement (when reported) and the missing association between the amount of proteinuria and tubulointerstitial fibrosis or the presence of glomerulosclerosis, points toward a primary tubulointerstitial process leading to glomerular sclerosis. This fits with the strong association between glomerulosclerosis and tubulointerstitial fibrosis, which was also found by Theilig et al. in megalinknockout mice [74]. In their model, megalin deficiency was associated with increased apoptosis at baseline, which was accentuated following induction of anti-glomerular-basementmembrane (GBM) nephritis. Recent studies in a model of isolated proximal tubular damage have shown that tubulointerstitial injury can lead to glomerulosclerosis $[75,76]$.

Reports regarding RAAS inhibition in Dent disease are scarce, and most of them report disappointing results. RAAS inhibition is the treatment of choice for glomerular proteinuria originating either from glomerulonephritis, Alport syndrome, or primary or secondary FSGS. Based on the strong association between urinary albumin excretion and renal endpoints, Heerspink and Gansevoort argue that normalization of urinary albumin excretion should be a therapeutic target per se [77]. They show that the beneficial effect of RAAS inhibition is conveyed via normalization of albuminuria. Does this also apply to albuminuria resulting from defective tubular reabsorption? There is a large body of evidence mostly from in vitro studies indicating that an overload of albumin in primary urine triggers a toxic effect and inflammatory response in proximal tubular cells conveyed via the megalin-cubilin system [77]. In their study on anti-GBM disease in megalin-knockout mice, Theilig et al. indeed observed increased expression of profibrotic markers in a megalin-dependent manner [74]. In this light, disturbed endocytosis - as in Dent disease - might be expected to protect the proximal tubular cells against the detrimental effects of albuminuria. However, tubulointerstitial fibrosis was most marked in knockout animals, leading the authors to challenge the view of protein overload causing tubulointerstitial damage. Norden et al. demonstrated tubular wasting of a wide variety of polypeptides, hormones (e.g., insulin, growth hormone, insulin-like growth factor-1), and chemokines (e.g., monocyte chemoattractant protein-1) [10]. Some of these have been implicated in the pathogenesis of tubulointerstitial fibrosis and may be the underlying mechanism for progressive renal failure in Dent disease.

Due to the nature of a review based on case reports, our study has several limitations: (i) The number of reported Dent-2 patients is far less than that of Dent-1 patients; therefore, nonparametric tests had to be used, which may have weakened the statistical power of our analysis. Still, the findings in both patient groups were virtually identical, indicating that our conclusion that Dent-1 and Dent- 2 are phenotypically identical as far as proteinuria is concerned holds true. (ii) Data were analyzed retrospectively, and data sets were incomplete for many parameters. In particular, for TPE, assumptions were made regarding BSA based on Dutch reference values, while the literature survey identified mostly patients from Asia and the Mediterranean. As the Dutch are taller on 
average than these populations, BSA has probably been overestimated in our analysis. Therefore, TPE will be even higher than estimated. The lower prevalence of NP by dipstick analysis compared with quantitative methods reflects the limitation of this test for detecting LMW proteinuria. Data on albuminuria was scarce, precluding a specific analysis of protein composition. (iii) In particular, in patients with high protein excretion, a publication bias cannot be excluded. However, the majority of reports did not focus on proteinuria and did not even discuss the amount of protein excretion, indicating that our findings on median protein excretion are representative for Dent patients. (iv) Patients were rather young in our series and had normal GFR. Also, there was insufficient data for serial analysis, and thus our data cannot be extrapolated to older Dent patients, and the prognostic role of proteinuria in Dent disease remains unclear. Here, prospective long-term studies are needed to evaluate the impact of proteinuria and hypercalciuria/nephrocalcinosis for the prognosis of Dent disease. Such studies are underway (http://www.rarekidneystones. org). Potential therapeutic interventions to be tested are thiazide diuretics, citrate, and RAAS inhibition [3]. Regardless, the slow natural course of Dent disease leading to end-stage renal disease in later adulthood is a major obstacle for prospective (interventional) studies. Animal studies such as the citrate trial in knockout mice performed by Cebotaru et al. [78] may be more informative than studies in humans using surrogate markers such as hypercalciuria [79] or proteinuria.

\section{Conclusion}

Nephrotic-range proteinuria is a common finding both in Dent- 1 and Dent-2 and reflects disturbed protein reabsorption in the proximal tubule rather than glomerular damage. The presence of LMW proteinuria is the hallmark of Dent disease and should be tested in patients with nephrotic-range proteinuria without edema and hypoalbuminemia in order to avoid potentially harmful immunosuppressive therapy and unnecessary renal biopsies. Even with normal renal function, glomerulosclerosis and tubulointerstitial fibrosis are already present in the majority of patients in childhood. The role of proteinuria in the course of the disease needs to be studied further in longitudinal (interventional) studies.

\section{Compliance with ethical standards}

Conflict of interest The authors declare no conflicts of interest.

Open Access This article is distributed under the terms of the Creative Commons Attribution 4.0 International License (http:// creativecommons.org/licenses/by/4.0/), which permits unrestricted use, distribution, and reproduction in any medium, provided you give appropriate credit to the original author(s) and the source, provide a link to the Creative Commons license, and indicate if changes were made.

\section{References}

1. Dent CE, Friedman M (1964) Hypercalcuric rickets associated with renal tubular damage. Arch Dis Child 39:240-249

2. Frishberg Y, Dinour D, Belostotsky R, Becker-Cohen R, Rinat C, Feinstein S, Navon-Elkan P, Ben-Shalom E (2009) Dent's disease manifesting as focal glomerulosclerosis: is it the tip of the iceberg? Pediatr Nephrol 24:2369-2373

3. Ludwig M, Utsch B, Monnens LA (2006) Recent advances in understanding the clinical and genetic heterogeneity of Dent's disease. Nephrol Dial Transplant 21:2708-2717

4. Thakker RV (2000) Pathogenesis of Dent's disease and related syndromes of X-linked nephrolithiasis. Kidney Int 57:787-793

5. Vrljicak K, Batinic D, Milosevic D, Nizic-Stancin L, Ludwig M (2011) A boy with Dent-2 disease. Coll Anthropol 35:925-928

6. Bockenhauer D, Bokenkamp A, Nuutinen M, Unwin R, Van't Hoff W, Sirimanna T, Vrljicak K, Ludwig M (2012) Novel OCRL mutations in patients with Dent-2 disease. J Pediatr Genet 1:15-23

7. Bokenkamp A, Ludwig M (2011) Disorders of the renal proximal tubule. Nephron Physiol 118:1-6

8. Wrong OM, Norden AG, Feest TG (1994) Dent's disease; a familial proximal renal tubular syndrome with low-molecular-weight proteinuria, hypercalciuria, nephrocalcinosis, metabolic bone disease, progressive renal failure and a marked male predominance. QJM 87:473-493

9. Devuyst O, Thakker RV (2010) Dent's disease. Orphanet J Rare Dis $5: 28$

10. Norden AG, Lapsley M, Lee PJ, Pusey CD, Scheinman SJ, Tam FW, Thakker RV, Unwin RJ, Wrong O (2001) Glomerular protein sieving and implications for renal failure in Fanconi syndrome. Kidney Int 60:1885-1892

11. Bokenkamp A, Bockenhauer D, Cheong HI, Hoppe B, Tasic V, Unwin R, Ludwig M (2009) Dent-2 disease: a mild variant of Lowe syndrome. J Pediatr 155:94-99

12. Israni A, Kasiske B (2004) Laboratory assessment of kidney disease: clearance, urinalysis, and kidney biopsy. Brenner and Rector's the kidney - 7th ed. Philadelphia: Saunders., United States, p 742

13. Copelovitch L, Nash MA, Kaplan BS (2007) Hypothesis: Dent disease is an underrecognized cause of focal glomerulosclerosis. Clin J Am Soc Nephrol 2:914-918

14. Fervenza FC (2013) A patient with nephrotic-range proteinuria and focal global glomerulosclerosis. Clin J Am Soc Nephrol 8:19791987

15. De Mutiis C, Pasini A, La Scola C, Pugliese F, Montini G (2015) Nephrotic-range Albuminuria as the presenting symptom of Dent-2 disease. Ital J Pediatr 41:46

16. Mosteller RD (1987) Simplified calculation of body-surface area. N Engl J Med 317:1098

17. Netherlands Organisation for Applied Scientific Research (TNO): 'Growth Chart Boys 0-15 Months' and 'Growth Chart Boys 1-21 Years': Fifth national growth studie 2010. http://www.tno. nl/en/focus-area/healthy-living/prevention-work-health/youthgrowing-up-healthy/pdf-growth-charts/

18. Norden AG, Scheinman SJ, Deschodt-Lanckman MM, Lapsley M, Nortier JL, Thakker RV, Unwin RJ, Wrong O (2000) Tubular proteinuria defined by a study of Dent's (CLCN5 mutation) and other tubular diseases. Kidney Int 57:240-249

19. Guder WG, Hofmann W (1993) Differentiation of proteinuria and haematuria by single protein analysis in urine. Clin Biochem 26: 277-282

20. Ravani P, Rossi R, Bonanni A, Quinn RR, Sica F, Bodria M, Pasini A, Montini G, Edefonti A, Belingheri M, De Giovanni D, Barbano G, Degl'Innocenti L, Scolari F, Murer L, Reiser J, Fornoni A, Ghiggeri GM (2015) Rituximab in children with steroiddependent nephrotic syndrome: a multicenter, open-label, 
noninferiority, randomized controlled trial. J Am Soc Nephrol 26: 2259-2266

21. Levey A, Coresh J (2002) Clinical practice guidelines for chronic kidney disease: evaluation, classification and stratification. National Kidney Foundation; http://www.kidney. org/sites/default/files/docs/ckd_evaluation_classification_ stratification.pdf

22. Schwartz GJHG, Edelmann CM Jr, Spitzer A (1976) A simple estimate of glomerular filtration rate in children derived from body length and plasma creatinine. Pediatrics 58:259-263

23. Levey AS, Coresh J, Greene T, Stevens LA, Zhang YL, Hendriksen S, Kusek JW, Van Lente F (2006) Using standardized serum creatinine values in the modification of diet in renal disease study equation for estimating glomerular filtration rate. Ann Intern Med 145: 247-254

24. Hichri H, Rendu J, Monnier N, Coutton C, Dorseuil O, Poussou RV, Baujat G, Blanchard A, Nobili F, Ranchin B, Remesy M, Salomon R, Satre V, Lunardi J (2011) From Lowe syndrome to Dent disease: correlations between mutations of the OCRL1 gene and clinical and biochemical phenotypes. Hum Mutat 32:379-388

25. IBM-Corp (Released 2013) IBM SPSS Statistics for Windows, Version 22.0. Armonk, NY: IBM Corp

26. Akuta N, Lloyd SE, Igarashi T, Shiraga H, Matsuyama T, Yokoro S, Cox JP, Thakker RV (1997) Mutations of CLCN5 in Japanese children with idiopathic low molecular weight proteinuria, hypercalciuria and nephrocalcinosis. Kidney Int 52:911-916

27. Anglani F, Bernich P, Tosetto E, Cara M, Lupo A, Nalesso F, D'Angelo A, Gambaro G (2006) Family history may be misleading in the diagnosis of Dent's disease. Urol Res 34:61-63

28. Becker-Cohen R, Rinat C, Ben-Shalom E, Feinstein S, Ivgi H, Frishberg Y (2012) Vitamin A deficiency associated with urinary retinol binding protein wasting in Dent's disease. Pediatr Nephrol 27:1097-1102

29. Besbas N, Ozaltin F, Jeck N, Seyberth H, Ludwig M (2005) CLCN5 mutation (R347X) associated with hypokalaemic metabolic alkalosis in a Turkish child: an unusual presentation of Dent's disease. Nephrol Dial Transplant 20:1476-1479

30. Bogdanovic R, Draaken M, Toromanovic A, Crossed Devic M, Stajic N, Ludwig M (2010) A novel CLCN5 mutation in a boy with Bartter-like syndrome and partial growth hormone deficiency. Pediatr Nephrol 25:2363-2368

31. Carballo-Trujillo I, Garcia-Nieto V, Moya-Angeler FJ, AntonGamero M, Loris C, Mendez-Alvarez S, Claverie-Martin F (2003) Novel truncating mutations in the ClC-5 chloride channel gene in patients with Dent's disease. Nephrol Dial Transplant 18: 717-723

32. Cheong HI, Lee JW, Zheng SH, Lee JH, Kang JH, Kang HG, Ha IS, Lee SJ, Choi Y (2005) Phenotype and genotype of Dent's disease in three Korean boys. Pediatr Nephrol 20:455-459

33. Claverie-Martin F, Gonzalez-Acosta H, Flores C, Anton-Gamero M, Garcia-Nieto V (2003) De novo insertion of an Alu sequence in the coding region of the CLCN5 gene results in Dent's disease. Hum Genet 113:480-485

34. Cramer MT, Charlton JR, Fogo AB, Fathallah-Shaykh SA, Askenazi DJ, Guay-Woodford LM (2014) Expanding the phenotype of proteinuria in Dent disease. A case series. Pediatr Nephrol 29:2051-2054

35. Dinour D, Davidovitz M, Levin-Iaina N, Lotan D, Cleper R, Weissman I, Knecht A, Holtzman EJ (2009) Truncating mutations in the chloride/proton ClC-5 antiporter gene in Seven Jewish Israeli families with Dent's 1 disease. Nephron Clin Pract 112:c262-267

36. Hellemans R, Verpooten GA, Bosmans JL (2010) A young man presenting with recurrent nephrolithiasis. NDT Plus 3:584-587

37. Hoopes RR Jr, Hueber PA, Reid RJ Jr, Braden GL, Goodyer PR, Melnyk AR, Midgley JP, Moel DI, Neu AM, VanWhy SK, Scheinman SJ (1998) CLCN5 chloride-channel mutations in six new North American families with X-linked nephrolithiasis. Kidney Int 54:698-705

38. Igarashi T, Inatomi J, Ohara T, Kuwahara T, Shimadzu M, Thakker RV (2000) Clinical and genetic studies of CLCN5 mutations in Japanese families with Dent's disease. Kidney Int 58:520-527

39. Igarashi T, Gunther W, Sekine T, Inatomi J, Shiraga H, Takahashi S, Suzuki J, Tsuru N, Yanagihara T, Shimazu M, Jentsch TJ, Thakker RV (1998) Functional characterization of renal chloride channel, CLCN5, mutations associated with Dent'sJapan disease. Kidney Int 54:1850-1856

40. Kaneko K, Hasui M, Hata A, Hata D, Nozu K (2010) Focal segmental glomerulosclerosis in a boy with Dent-2 disease. Pediatr Nephrol 25:781-782

41. Kelleher CL, Buckalew VM, Frederickson ED, Rhodes DJ, Conner DA, Seidman JG, Seidman CE (1998) CLCN5 mutation Ser244Leu is associated with $\mathrm{X}$-linked renal failure without $\mathrm{X}$ linked recessive hypophosphatemic rickets. Kidney Int 53:31-37

42. Langlois V, Bernard C, Scheinman SJ, Thakker RV, Cox JP, Goodyer PR (1998) Clinical features of X-linked nephrolithiasis in childhood. Pediatr Nephrol 12:625-629

43. Li P, Huang JP (2009) Phenotype and genotype of Dent's disease in three Chinese boys. Nephrology (Carlton) 14:139-142

44. Lim IS, Yun KW, Moon KC, Cheong HI (2007) Proteinuria in a boy with infectious mononucleosis, C1q nephropathy, and Dent's disease. J Korean Med Sci 22:928-931

45. Lloyd SE, Pearce SH, Gunther W, Kawaguchi H, Igarashi T, Jentsch TJ, Thakker RV (1997) Idiopathic low molecular weight proteinuria associated with hypercalciuric nephrocalcinosis in Japanese children is due to mutations of the renal chloride channel (CLCN5). J Clin Invest 99:967-974

46. Lozanovski VJ, Ristoska-Bojkovska N, Korneti P, Gucev Z, Tasic V (2011) OCRL1 mutation in a boy with Dent disease, mild mental retardation, but without cataracts. World J Pediatr 7:280-283

47. Marsenic O, Kaplan BS (2009) Hydrochlorothiazide-induced tubulointerstitial nephritis in a patient with Dent disease. NDT Plus 2:264-265

48. Matsuyama T, Awazu M, Oikawa T, Inatomi J, Sekine T, Igarashi T (2004) Molecular and clinical studies of Dent's disease in Japan: biochemical examination and renal ultrasonography do not predict carrier state. Clin Nephrol 61:231-237

49. Morimoto T, Uchida S, Sakamoto H, Kondo Y, Hanamizu H, Fukui M, Tomino Y, Nagano N, Sasaki S, Marumo F (1998) Mutations in CLCN5 chloride channel in Japanese patients with low molecular weight proteinuria. J Am Soc Nephrol 9:811-818

50. Nakazato H, Yoshimuta J, Karashima S, Matsumoto S, Endo F, Matsuda I, Hattori S (1999) Chloride channel CLCN5 mutations in Japanese children with familial idiopathic low molecular weight proteinuria. Kidney Int 55:63-70

51. Nakazato H, Hattori S, Furuse A, Kawano T, Karashima S, Tsuruta M, Yoshimuta J, Endo F, Matsuda I (1997) Mutations in the CLCN5 gene in Japanese patients with familial idiopathic lowmolecular-weight proteinuria. Kidney Int 52:895-900

52. Okamoto T, Tajima T, Hirayama T, Sasaki S (2012) A patient with Dent disease and features of Bartter syndrome caused by a novel mutation of CLCN5. Eur J Pediatr 171:401-404

53. Ramos-Trujillo E, Garcia-Nieto V, Gonzalez-Acosta H, Vara J, Perez-Diaz V, Nadal I, Oliveros R, Claverie-Martin F (2007) Molecular analysis of the CLCN5 gene in Dent's disease: first mutation identified in a patient from South America. Clin Nephrol 68: $367-372$

54. Samardzic M, Pavicevic S, Ludwig M, Bogdanovic R (2011) Effect of growth hormone replacement therapy in a boy with Dent's disease: a case report. J Med Case Rep 5:400

55. Sekine $\mathrm{T}$, Nozu K, Iyengar R, Fu XJ, Matsuo M, Tanaka R, Iijima K, Matsui E, Harita Y, Inatomi J, Igarashi T (2007) OCRL1 
mutations in patients with Dent disease phenotype in Japan. Pediatr Nephrol 22:975-980

56. Sethi SK, Ludwig M, Kabra M, Hari P, Bagga A (2009) Vitamin A responsive night blindness in Dent's disease. Pediatr Nephrol 24: $1765-1770$

57. Sheffer-Babila S, Chandra M, Speiser PW (2008) Growth hormone improves growth rate and preserves renal function in Dent disease. J Pediatr Endocrinol Metab 21:279-286

58. Takemura T, Hino S, Ikeda M, Okada M, Igarashi T, Inatomi J, Yoshioka K (2001) Identification of two novel mutations in the CLCN5 gene in Japanese patients with familial idiopathic low molecular weight proteinuria (Japanese Dent's disease). Am J Kidney Dis $37: 138-143$

59. Tasic V, Lozanovski VJ, Korneti P, Ristoska-Bojkovska N, SabolicAvramovska V, Gucev Z, Ludwig M (2011) Clinical and laboratory features of Macedonian children with OCRL mutations. Pediatr Nephrol 26:557-562

60. Tosetto E, Addis M, Caridi G, Meloni C, Emma F, Vergine G, Stringini G, Papalia T, Barbano G, Ghiggeri GM, Ruggeri L, Miglietti N, Da A, Melis MA, Anglani F (2009) Locus heterogeneity of Dent's disease: OCRL1 and TMEM27 genes in patients with no CLCN5 mutations. Pediatr Nephrol 24:1967-1973

61. Tosetto E, Ghiggeri GM, Emma F, Barbano G, Carrea A, Vezzoli G, Torregrossa R, Cara M, Ripanti G, Ammenti A, Peruzzi L, Murer L, Ratsch IM, Citron L, Gambaro G, D'Angelo A, Anglani F (2006) Phenotypic and genetic heterogeneity in Dent's disease-the results of an Italian collaborative study. Nephrol Dial Transplant 21:24522463

62. Utsch B, Bokenkamp A, Benz MR, Besbas N, Dotsch J, Franke I, Frund S, Gok F, Hoppe B, Karle S, Kuwertz-Broking E, Laube G, Neb M, Nuutinen M, Ozaltin F, Rascher W, Ring T, Tasic V, van Wijk JA, Ludwig M (2006) Novel OCRL1 mutations in patients with the phenotype of Dent disease. Am J Kidney Dis 48(942):e114

63. Vaisbich MH, Henriques Ldos S, Igarashi T, Sekine T, Seki G, Koch VH (2012) The long-term use of enalapril and hydrochlorothiazide in two novel mutations patients with Dent's disease type 1 . J Bras Nefrol 34:78-81

64. Yanagida H, Ikeoka M, Kuwajima H, Wada N, Tabata N, Sugimoto K, Okada M, Takemura T (2004) A boy with Japanese Dent's disease exhibiting abnormal calcium metabolism and osseous disorder of the spine: defective megalin expression at the brushborder of renal proximal tubules. Clin Nephrol 62:306-312

65. Zhang H, Wang C, Yue H, Hu WW, Gu JM, He JW, Fu WZ, Liu YJ, Zhang Z, Zhang ZL (2014) Identification of a novel mutation in the CLCN5 gene in a Chinese family with Dent-1 disease. Nephrology (Carlton) 19:80-83
66. Yildiz N, Deniz NC, Altuntas U, Gokce I, Alpay H (2013) Dent's disease in a child with nephrolithiasis. Turk J Pediatr 48:347-349

67. Ji LN, Chen CY, Wang JJ, Cao L (2014) A novel CLCN5 mutation in a Chinese boy with Dent's disease. World J Pediatr 10:275-277

68. Herget-Rosenthal S, van Wijk JA, Brocker-Preuss M, Bokenkamp A (2007) Increased urinary cystatin $C$ reflects structural and functional renal tubular impairment independent of glomerular filtration rate. Clin Biochem 40:946-951

69. Ceol M, Tiralongo E, Baelde HJ, Vianello D, Betto G, Marangelli A, Bonfante L, Valente M, Della Barbera M, D'Angelo A, Anglani F, Del Prete D (2012) Involvement of the tubular ClC-type exchanger $\mathrm{ClC}-5$ in glomeruli of human proteinuric nephropathies. PLoS One 7:e45605

70. Erb BC, Velazquez H, Gisser M, Shugrue CA, Reilly RF (1997) cDNA cloning and localization of OCRL-1 in rabbit kidney. Am J Physiol 273:F790-795

71. Tojo A, Kinugasa S (2012) Mechanisms of glomerular albumin filtration and tubular reabsorption. Int J Nephrol 2012:481520

72. Dickson LE, Wagner MC, Sandoval RM, Molitoris BA (2014) The proximal tubule and albuminuria: really! J Am Soc Nephrol 25: $443-453$

73. Ovunc B, Otto EA, Vega-Warner V, Saisawat P, Ashraf S, Ramaswami G, Fathy HM, Schoeb D, Chernin G, Lyons RH, Yilmaz E, Hildebrandt F (2011) Exome sequencing reveals cubilin mutation as a single-gene cause of proteinuria. J Am Soc Nephrol 22:1815-1820

74. Theilig F, Kriz W, Jerichow T, Schrade P, Hahnel B, Willnow T, Le Hir M, Bachmann S (2007) Abrogation of protein uptake through megalin-deficient proximal tubules does not safeguard against tubulointerstitial injury. J Am Soc Nephrol 18:1824-1834

75. Lee PT, Chou KJ, Fang HC (2012) Are tubular cells not only victims but also perpetrators in renal fibrosis? Kidney Int 82:128-130

76. Grgic I, Campanholle G, Bijol V, Wang C, Sabbisetti VS, Ichimura T, Humphreys BD, Bonventre JV (2012) Targeted proximal tubule injury triggers interstitial fibrosis and glomerulosclerosis. Kidney Int 82:172-183

77. Heerspink HJ, Gansevoort RT (2015) Albuminuria is an appropriate therapeutic target in patients with CKD: the Pro view. Clin J Am Soc Nephrol 10:1079-1088

78. Cebotaru V, Kaul S, Devuyst O, Cai H, Racusen L, Guggino WB, Guggino SE (2005) High citrate diet delays progression of renal insufficiency in the ClC-5 knockout mouse model of Dent's disease. Kidney Int 68:642-652

79. Raja KA, Schurman S, D'Mello RG, Blowey D, Goodyer P, Van Why S, Ploutz-Snyder RJ, Asplin J, Scheinman SJ (2002) Responsiveness of hypercalciuria to thiazide in Dent's disease. J Am Soc Nephrol 13:2938-2944 